\title{
STRATEGIES FOR CONSERVATION OF RET MEDICINAL PLANTS OF SOUTH INDIA
}

\author{
K. Manivannan \\ Department of Horticulture, Faculty of Agriculture, Annamalai University \\ Annamalainagar - 608002 , Tamil Nadu, India \\ E-Mail: manihort@yahoo.co.in
}

\begin{abstract}
India is rich in medicinal plants diversity. The RET (Rare, Endangered and Threatened) medicinal plants which have been identified by IUCN are to be conserved by both in-situ and ex-situ methods. Ex-situ conservation of medicinal plant species is a complementary action to conserve the genetic diversity of prioritized medicinal plants. It is especially desirable in case of species where wild populations have dwindled to critical levels. In the present study, six potential RET medicinal plants viz. Decalepis hamiltonii, Gloriosa superba, Holostemma-ada-kodien, Salacia reticulata and Tinospora sinensis found in South India were explored, collected and conserved for sustainable utilization. The specific objectives of the study was to explore the status and distribution of the above RET species in the North and Coastal Tamil Nadu. A total of thirty three plants with a maximum of fifteen in Gloriosa superba, eight in Decalepis hamiltonii, four each in Holostemma-ada-kodien and Salacia reticulata and two in Tinospora sinensis were collected and their growth parameters were recorded. In Gloriosa sp., flowering and fruiting were observed and the seeds were collected from different accessions. Based on the observations, data base was generated for documentation.
\end{abstract}

Key words: Medicinal plants, Rare, Endangered, Threatened, Exploration, Conservation.

\section{INTRODUCTION}

The rapid loss of biodiversity globally and especially in developing countries has become the subject of increasing national and international concern. This is evidenced in the substantial increase in the interest accorded to biodiversity by governments and financial aid by donors and conservation organizations. Human activities are rapidly reducing the planet's life supporting capacity. The ever increasing human population places heavy demand on the bioresources. The impact and pressure on the nature is quiet conspicuous and the onus is seen on the forest resources with depletion of biological diversity, which has become a sever ecological problem (Soul, 1991). Forests are the cradles of biodiversity and are one of the most important renewable nature resources. Biodiversity is termed as the 'species richness' in a habitat in a given time and is critical to the health and stability of the biosphere and renewability of the biomass, soil and other related aspects.

The over exploitation of the resources and deforest action brought about by indiscriminate logging in the tropical forests has resulted in depletion of biodiversity and the serious situation may worsen in due course if left unchecked. The main threat to tropical biodiversity is habitat loss (Bowels et al, 1998).

\section{EX-SITU CONSERVATION AND DOMESTICATION OF RET MEDICINAL PLANTS}

It is very much essential to develop ex-situ gene bank of the RET species which are becoming extinct and also to addition, domestication of these important medicinal plants and their cultivation for sustainable utilization will go a long way for the benefit of mankind. 
India is one of the twelve mega biodiversity countries of the World, harbours 45,000 described plant species of which 15,000 to 20,000 possess proves medicinal value. Out of 900 major medicinal plants available in India, about $10 \%$ is highly threatened due to various reasons. In India, the unsustainable collection of medicinal plants from the wild for commercial purpose and habitat destruction due to urbanization stand high among the human induced causes of depletion of medicinal plant population.

Quantitative assessment of the status and distribution of medicinal plants is indispensable for proper management of the plant resources. The lack of authentic information on the status and distribution leads to various kinds of inconveniences including mismanagement of medicinal plant wealth. At the same time, identification of genetic variations of medicinal plant species and their mass multiplication and conservation have become an important task in the sustainable and equitable use of the enormous and invaluable genetic diversity found in the country (Wilcove, 1989).

Keeping these values in focus, Department of Horticulture, Annamalai University has undertaken such an endeavor in the Northern districts and the Coastal region of Tamil Nadu. Our focus is mainly exploration, collection and ex-situ conservation of five RET medicinal plants. The specific objectives of our programme are:

1. To explore the status and distribution of five RET medicinal plants in North and Coastal Tamil Nadu.

2. To collect and conserve all the possible varients of target species ex-situ in the conservatory.

3. To document the information related to the target species and location and develop a data base

\section{MATERIALS AND METHODS}

The following RET Medicinal plants were chosen for the exploration and conservation.

1. Decalepis hamiltonii

2. Gloriosa superba

3. Holostemma ada-kodian

4. Salacia reticulata

5. Tinospora sinensis

\section{Decalepis hamiltonii Wight and Arn}

$\begin{array}{lll}\text { Family } & : & \text { Asclepiadaceae } \\ \text { Common Name } & : & \text { Mahali kizhangu } \\ \text { Threat status } & : & \text { Endangered } \\ \text { Used in } & : & \text { Ayurveda, Folk and Sidha }\end{array}$

Common uses

The roots of mahali-kizhangu are used in the form of powder and infusion to treat wound and bronchial asthma. The tuberous roots are used as cooling agent and blood purifier.

Habitate: In open rockey slopes and rockey cervices of dry to moist deciduous place/forests.

\section{Gloriosa superba, L.}

Family

Liliaceae

Common Name $\quad: \quad$ Kalapai kilangu

Threat status : $\quad$ Endangered

Used in : $\quad$ Ayurvedha, Sidha

Common uses

Proceedings of the 15 ${ }^{\text {th }}$ International Forestry and Environment Symposium, 26-27 November 2010

Published by Department of Forestry and Environmental Science, University of Sri Jayewardenepura, Sri Lanka. 
The tuberous roots are useful in curing inflammations, ulcers, bleeding piles, skin diseases, snake bite, baldness etc.

Habitate - Sea-level to semi evergreen forests.

\section{Holostemma ada-kodien Schulf.}

$\begin{array}{lll}\text { Family } & : & \text { Asclepiadaceae } \\ \text { Common name } & : & \text { Palaikkirai } \\ \text { Threat status } & : & \text { Vulnerable/ Regional } \\ \text { Used in } & : & \text { Ayurveda and Folk }\end{array}$

Common uses:

The roots and leaves are used in the form of powder and juice to treat spider poisoning, fever with burning.

Habitate: Dry and moist deciduous forest.

\section{Salacia reticulata}

$\begin{array}{lll}\text { Family } & : & \text { Hippocrateaceae } \\ \text { Common Name } & : & \text { Ponkoranthi or Kadal Azhinchal } \\ \text { Threat status } & : & \text { Rare } \\ \text { Used in } & : & \text { Ayurvedha, Folk and Siddha }\end{array}$

Common uses: Roots are used in diabetes, haemorrhoids, leucorrhea, leprosy, skin diseases, wounds, ulcers and liver disorders.

Habitate: In open marshy forests of Coastal regions.

\section{Tinospora sinensis (Lour).}

$\begin{array}{lll}\text { Family } & : & \text { Menispermaceae } \\ \text { Common name } & : & \text { Chintil kodi } \\ \text { Threat status } & : & \text { Vulnarable } \\ \text { Used in } & : & \text { Ayurveda and Folk medicine }\end{array}$

Common uses

Dried stem are used in fever, jaundice, thirst, burning sensation, diabetes, piles, skin ailments and respiratory disorders. It also improves intellect and impart youthfulness, vitality and longevity.

Habitate: Ever green moist deciduous forests.

\section{RESULTS AND DISCUSSION}

The field of plant conservation includes the study of plant decline and its causes, techniques to conserve rare and endangered plants. Medicinal plant conservation can be considered a part of conservation biology, a relatively young field that emphasizes the conservation of medicinal plant biodiversity and whole ecosystems, as opposed to the conservation of individual species. In the present study focus was given mainly to five important RET medicinal plants of greater values.

\section{Decalepis hamiltonii}

This medicinal plant, which is commonly known as Mahali kilangu in Tamil was found in wild in the moderate hill ranges of Pachamalai, Andherr malai and Sirumalai, in three different locations of Tamil Nadu in India besides some other places of South India. 


\begin{tabular}{|l|l|l|l|l|}
\hline 1. & Collection site & $1 . \quad$ Pachamalai & $2 . \quad$ Andhermalai & 3. Sirumalai \\
\hline 2. & Latitude & $11^{0} 22^{\prime} 54.56^{\prime} \mathrm{N}$ & $12^{0} 07^{\prime} 52.31^{\prime \prime} \mathrm{N}$ & $10^{0} 07^{\prime} 43.42^{\prime \prime} \mathrm{N}$ \\
\hline 3. & Longitude & $78^{0} 41^{\prime} 11.68^{\prime} \mathrm{E}$ & $77^{0} 53^{\prime} 52.31^{\prime \prime} \mathrm{E}$ & $78^{0} 05^{\prime} 06.58^{\prime \prime} \mathrm{E}$ \\
\hline 4. & Elevation & $682^{\prime}$ & $1653^{\prime}$ & $1604^{\prime}$ \\
\hline 5. & Collection source & Wild & Wild & Wild \\
\hline 6. & Population size & 4 & 6 & 2 \\
\hline 7. & Sample status & Endangered & Threatened & Threatened \\
\hline 8. & Types of sample & $\begin{array}{l}\text { Fruits / Individual } \\
\text { plant }\end{array}$ & Individual plant & Individual plant \\
\hline
\end{tabular}

Biometric Observations:

\begin{tabular}{|l|l|l|l|}
\hline Accession No. & Vine Length $(\mathbf{c m})$ & Vine girth $\mathbf{( c m})$ & Leaf area $(\mathbf{s q .}$ cm) \\
\hline DH-1 & 187 & 2.05 & 50.4 \\
\hline DH-2 & 190 & 1.83 & 56.1 \\
\hline DH-3 & 170 & 1.62 & 62.6 \\
\hline DH-4 & 151 & 1.43 & 35.5 \\
\hline DH-5 & 203 & 1.63 & 37.5 \\
\hline DH-6 & 221 & 1.02 & 37.2 \\
\hline
\end{tabular}

Based on the leaf area, we could identify two distinctive variations among the accessions. The seeds collected from the pods were dried and sown in seed trays and it took 42 days for germination. The hardened three months old seedlings were planted in the field where they have put forth new flushes. We could also notice the tuberization of their roots within four months of planting.

\section{Gloriosa superba}

During the exploration of the Kodiakarai reserve forest of swampy areas, normally spread tubers of 2 population were collected and planted in the field for observations. Anther three 


\section{Holostemma ada-kodian}

The RET medicinal plant, Palaikerai is a threatened sp. In the Cutralam hill ranges, in which four populations were found beneath the lemon grass patches. In every summer when the forest fire occurs and engulfs the dry lemon grasses, Holostemma will also get destroyed. Fortunately because of the tuberous roots in the chola soil, they sprout again during the South - West monsoon in the months of May - June.

\begin{tabular}{|l|l|l|l|l|}
\hline Accession No. & $\begin{array}{l}\text { Vine Length } \\
(\mathbf{c m})\end{array}$ & $\begin{array}{l}\text { Vine girth } \\
(\mathbf{c m})\end{array}$ & $\begin{array}{l}\text { Leaf area (sq. } \\
\text { (m) }\end{array}$ & $\begin{array}{l}\text { Days } \\
\text { flowering }\end{array}$ \\
\hline HA-1 & 263.0 & 1.26 & 48.6 & 68 \\
\hline HA -2 & 162.0 & 1.42 & 46.4 & 70 \\
\hline HA -3 & 242.0 & 1.84 & 68.2 & 62 \\
\hline HA -4 & 249.0 & 1.86 & 70.4 & 64 \\
\hline
\end{tabular}

Among the four population, HA-3 was early to flower in 62 days and the number of flowers were also high.

\section{Salacia reticulata}

During the exploration of Kodiakari reserve forest of the East Cost region, four populations of S.reticulata were located and their plants were collected as root suckers. Another sp. Known as Salacia chinansis was found in the Pichandikulam jungle of Pondicherry . Eight seedlings of this species were collected and planted in the field gene bank.

\section{Tinospora sinensis}

The wild species of it which is commonly known as cinthil kodi has been located in the kolli hills. Two populations were identified and their stem cuttings were put in the Mist chamber for multiplication and conservation. Further emphasis has been given for their large scale multiplication and to study their adoption for ex-situ conservation in the field gene bank in our herbal garden.

\section{CONCLUSION}

Conservation of medicinal plants in its biocultural perspective not only implies conservation of biodiversity but also places an equal emphasis on conservation of cultural diversity. The debilitating ecological consequences of monoculture in biological life are well known. The effects of promoting a monoculture in the civilisational context is only now being recognized. Hence, we have to give emphasis for the conservation of RET medicinal plants.

\section{ACKNOWLEDGEMENT}

The financial support given by National Medicinal Plants Board, Government of India is greatly acknowledge.

\section{REFERENCES}

Bowles, I.A., Rice, R.E. Mittermeier, R.A. 1998. Logging and tropical forest conservation. Science, 280: 1899-1900.

Soule, M.E. 1991. Conservation taffies for the constant crisis. Science, 253: 744-750.

Wilcove, D.S. 1989. Protecting bio diversity in multiple use lands: Lessons from the U.S. forest service. Trends Ecol. Evol., 4: 835-388. 